\title{
Education and School Administration in the Nigerian History: The Colonial and Post-Colonial Characteristics
}

\author{
Abdulrahman Yusuf Maigida \\ Department of Educational Foundations, \\ Faculty of Education \\ University of Port Harcourt.
}

\begin{abstract}
School administration in Nigeria is becoming much more issue that the society, the practitioners and all stakeholders discuss with concern, particularly with changing output of the system which some people condemn for reason, not far from retrogressive quality delivery. It is good to say that gone were those days that Nigeria was rated high in the practice of modern education. Today, it is clear that so many things are wrong. This paper is not to evaluate or assess how far the administration of school in Nigeria is faring, but tried to be historical in chronicling how we have come to where we are. The manifestations in the characteristics of school administration from colonial Nigeria, where colonial government was associated with educational administration while the missionaries and voluntary agencies with school administration. Now in the post-colonial period, where government is responsible entirely for educational administration with a number of regulatory agencies and private organisations/individuals, religious bodies and voluntary agencies are in the administration of schools. The paper used some templates from other advanced practice to further provide insights into what is obtainable in the contemporary Nigeria. The problems associated with school administration in general and specifically in Nigeria were highlighted, with some recommendations emphasizing that stakeholders should play by the rules.
\end{abstract}

Keywords: Education, School Administration, Nigerian History, Colonial and Post-colonial Characteristics

\section{Introduction}

The distinction that exists between educational administration and school administration is only delineable with thin line. Educational administration is broader and from it, the school administration takes off. School administration is associated with the day to day running of schools having appointed officers according Learn.org (2018), overseeing the daily operations of schools, colleges, universities, day care centres and preschools. Learn.org goes further to remark that a school administrator's specific responsibilities differ between organizations, but often, these administrators are an important link between students and local communities. However, Educational administration is seen to be extensive than school administration, therefore captures a range of professionals - from supervisors, programme administrators, and principals to deans, department heads, and chief academic officers - as well as organisations formed to administer school function (Rand, 2018).
Extensiveness of educational administration is further attested by Wikipedia (2017), recognizing it as a discipline within the study of education that examines the administrative theory and practice of education in 'general' and educational institutions and educators in particular activities.

The distinction between concepts is actually not the thrust of the paper, but necessary to midwife the discussion as a contemporary issue in education, which the failure to be retrospective in groping the contemporary is as good as not even dabble into educational appraisal at all. The examination of any contemporary issue has always been necessitated from an assessment or evaluation of the current situations about school administration as being disappointing or yet to meet the contemporary requirements and expectations. However, these disappointing situations must have been triggered by a number of factors that are best examined from the viewpoints of its causes before looking at the 
effects, so the cause and effect are two major considerations for this historical submission, as applied in this study.

Lending voice to the importance of giving the past a consideration in assessing the current trends, Foster (1980) maintains that "an understanding of the dynamics of earlier educational development is crucial, since these may indicate present constraints within which realistic planning must take place. It therefore suffices that the past issues, factors and characteristics have significant roles to play in the current school administration practice and for the future of school administration to hold something praiseworthy for the country.

Whatever that is considered or seen in the view of Abdulrahman (2014) as 'present' issue goes very fast into the 'past' which means that anything regarded as contemporary in terms of school administration in Nigeria immediately becomes subject of perusal or examination to ascertaining its substance and relevance in the context of existing educational manifestations. These existing educational manifestations leave us with the appraisal of forces and causes (dynamism) that produced such manifestations. The causes and forces in this regard become the elements of the past. In short, knowing the 'how' we have come to the contemporary level gives us a better idea of 'what' was wrong, 'how' it was wrong and 'why' it was wrong which means the appraisal of the existing or current manifestations with a total and deserved attention.

\section{Conceptual Examination of School Administration}

To be more exact about this concept of school administration, it can simply be explained in a straight forward statement as 'looking after the complete affairs related to school. In fact it is the managerial skill for smooth functioning and execution'. Also from the Glossary of Education (2012), the concept of school administration is viewed as the task of planning, organizing, directing, and controlling human or material resources within a school, college, or university. This definition directly points to the fact that school has its own administrative team that are saddled with the task of planning, organising, directing and controlling. This team of administrators found in the school system include the principal as the head of school administration, followed by the vice principal(s), the Head of
Departments, form masters and subject teachers, as it is in the case of secondary level of education.

In his contribution, Johnson (2012) explains that school administration is the school's main governing body, and it plays a major part in making decisions related to students, faculty and the school's overall status. There are several types of school administration, depending on the school's nature. These administrations oversee the school's development as well as the welfare of its students and faculty. More often, they are also the only entity that bridges the relationship between the school and the community.

\section{School Administration in the History}

Historically, any attempt to deal with issue of school administration in Nigeria can be gleaned from three (3) perspectives, thus:

(i) the missionaries' administration of their schools

(ii) Colonial involvement (Government) Educational administration and

(iii) school administration derived from educational administration.

Clarifying the above, what can be regarded as school administration started with the missionaries internally running their schools without government's involvement. Later on, the scope of administration was enlarged beyond school administration to educational administration with the colonial government's involvement through policy formulation and overall legislation and management of entire education by the government till today. From these government legislations and management of Nigerian education, the school administration at that level sourced its operations and instrumentality.

Issue concerning school administration is not recent but it is as old as the introduction of formal education and schooling in Nigeria. Historically, what can be regarded as the beginning of school administration in Nigeria can be credited to the effort made by the Portuguese Catholic Missionaries who established a school at the palace of Oba of Benin around the year 1515 . This school was administered by these Portuguese missionaries who by their requirements, according to Fafunwa (1974) states that this educational opportunity was only extended to children of Oba and his chiefs. 
In a more serious and precise way of looking at school administration in Nigeria and as a follow up to the first missionary's effort of 1515, the British colonial cum-missionaries presence is a very pertinent and unique yardstick to be considered in capturing the evolution of school administration in Nigeria. Starting from the introduction of formal education in Nigeria, which with the coming of the Wesleyan Methodist on the 24th day of September, 1842; and her establishment of the first primary school at Badagry was a major milestone. This Christian missionary's establishment of primary school marked the beginning of what can be called school management and administration in Nigeria.

Following the presence of Wesleyan Methodist and the establishment of a school in Badagry in 1842, several other missionaries came, not excluding Church Missionary Society which arrived on 19th December, 1842 and Presbyterian Church of Scotland, 1846. Others were Qua Iboe Mission, Southern Baptist Convention, Roman Catholic Mission, Sudan Interior Mission of the Baptist, Primitive Methodist Missionary Society and a host of others. With the presence of these missionaries in Nigeria and their spirit of evangelism, they wasted no time in the establishment of mission houses, churches and schools in places like Badagry, Abeokuta, Calabar, Onitsha, Lagos, Ibadan, Ijaiye, Ogbomosho, Iseyin, Ishaga, Ketu, Akassa, Bonny and other places.

Administratively, the missionaries' roles in the business of formal Western education in Nigeria cannot be treated with a wave of hand. Missionaries remained the major educators and managers of education provided to Nigerians in a formal way for nothing less than forty (40) years before the colonial education voice was heard. Throughout the period of missionaries' educational activities, the colonial government was silent, so the monopoly of educational activities continued with each of the missionary bodies providing education the way and manner it appealed to them or based on their denominational doctrines and principles. These differences gave rise to varying characters/features of Nigerian education, with standard being compromised. The differences was not unconnected with the goals of missionaries' presence in the country which was for soul winning, spreading of gospel or evangelism and not giving education in actual sense, this was the reason why Boyd and King (1981:100) lament that:

...the church undertook the business of education, not because it regarded education as good in itself, because it found that it could not do its own proper work without giving its adherents, and especially its clergy, as much of the formal learning as was required for the study of the sacred writings and for the performance of their religious duties.

Despite that the original intention was not to educate Nigerians as indicated above, kudos must still be given to the missionaries for their efforts. The colonial government which one would have believed to champion education of Nigerians from the beginning accorded it no attention until after 40 years as earlier mentioned.

Nevertheless and having observed by the colonial government that unguided missionaries' educational provision which was entirely religious or faith-based, had a shallow curriculum according to Ajayi and Oni (1992) that consisted of only the 3Rs 'Reading, wRiting and aRithmetic'. For a long time, the schools were solely organized, controlled and managed by the different Christian missionaries. This monopoly had with it, some accompanied problems which were identified in the operation of the early mission schools as highlighted by Osokoya (1985), thus:

i. lack of central school laws; leading to nonuniform standard for running schools;

ii. the schools lacked standard qualification for teachers;

iii. the movement of teachers and pupils was not checked resulting to irregular attendance;

iv. the focus of the school was religion;

v. there was acute shortage of fund and this affected the availability of qualified teachers;

vi. there were no trained teachers and no training colleges;

vii. there was lack of common syllabus and no standard textbooks; the few that were available were not relevant to the local people;

viii. the school lacked adequate supervision as well as teaching and learning materials and necessary facilities;

ix. there was no regulated standard examination for all the schools; 
x. there was no uniformity in teachers' condition of service and no job security for the teachers;

xi. in some cases, some older pupils were used to teach the younger ones; this affected quality;

xii. the method of teaching was mainly by rote;

xiii. it created the problem of educational imbalance between the northern and southern parts of Nigeria;

xiv. there was no serious interest and commitment shown by the missions in secondary and vocational education in Nigeria.

Despite the plethora of deficiencies that characterized the provision of education to the Nigerians by the missionaries, evangelism remained the priority and different missions continued to expand and extend by building more churches with schools as their adjuncts.

\section{Beginning of Government's Participation in Educational Administration}

On the part of the colonial administration, the genuine intention for their presence was also not to provide their colonial subjects (Nigerians) education, but political, military and commercial reasons. A care-free attitude to education was displayed by the colonial government. However, the colonial Government's partial involvement in educational business of Nigeria was first witnessed with the grants-in-aid of $£ 30$ pounds in 1872 to the three (3) missions (Osokoya, 1989). This grant by the colonial government can be appointed as the beginning of government's educational financing in Nigeria. With this grants, educational provision, administration and management were still not the concern of government, but was eventually compelled to be responsive through increased criticisms of education the missionaries were providing to Nigerians. The nationalists, traders and the Government's observations herself about the trends, culminated in the promulgation of 1882 Education Ordinance as first regulatory measure (law) to address education provided by the missionaries. To this extent, the Colonial Government took the courage in handing down guidelines to the missionaries and other voluntary agencies on how and what education to be given to their colonial subjects should be.

The 1882 Education Ordinance among others had provisions that included the following and were applicable to Lagos colony and Accra which were under one colonial Administration till 1886, thus:

a. The constitution of a General Board of education in places considered desirable;

b. The constitution, powers and duties of the Local Board of Education;

c. Classification of schools into:

i. Government schools which were maintained entirely through public funds.

ii. Assisted schools established by private persons and aided from public funds.

d. Freedom of parents as to religious instruction of their children;

e. Grants to be used for school buildings and teachers salaries;

f. Conditions of grants-in-aid to private schoolsbased on managerial control, attendance of children and examination results in specified subjects;

g. Appointment of an Inspector of Schools for all the British West Africa. When appointed the Inspector would spend most of his time in the Gold Coast. While Lagos would contribute one-third of the inspector's fixed annual salary of $£ 400$;

h. Special grants to be made to industrial schools;

i. Admission of pauper children into government and assisted schools;

j. Defining school curriculum to include Reading, Writing, English Language, Arithmetic and Needlework for girls.

k. Grants to training colleges and institutions for teachers.

Subsequently, several other Ordinances were evolved to respond to the educational requirements of the Nigerian people. Among these Ordinances was the 1887 Ordinance promulgated on 30th of May, exclusively for Nigeria (Lagos Colony). The 1887 Ordinance marked the beginning and foundation of education policies for Nigeria. This Ordinance was the first Government's demonstration of serious effort in promotion and control of education. The provisions of this Ordinance according to Ajayi and Oni (1992) included the constitution of a Board of Education; the appointment of an Inspector of schools and other Education Officers, grants-in-aid to schools and Teacher Training Institutions, Certificate of Teachers, establishment of scholarships for secondary and technical education students; and also power of Government to open and maintain Government schools. 
It is good to quickly mention here that all Education Ordinances that came before the 1916's were applicable to parts and not the entire Nigeria, because Nigeria geographically existed before 1914's Lugardian amalgamation as northern and southern protectorates. The two protectorates had two broad types of educational process and precolonial experience. In the submission of Osokoya (2012), they were two distinct protectorates of the British administration before the unification. Even from this amalgamation and the promulgation of the 1916 Education Ordinance, administration of education was still dualized.

In practice, 1916 produced both Ordinance and Codes for educational administration of the country on the 21st December and 24th December 1916 respectively. The Ordinance was applicable to both the north and south, but specifically, the Codes were only applied in the south. Both of them had significant impact on the education life of Nigeria, thus:

a. It was the first ordinance that took care of the whole country;

b. It provided for increased financial participation of government in the schools;

c. It also encouraged high level co-operation between the government and missions;

d. it brought a measure of Government control over education as a whole

The code which is operational in the South alone, prescribed new conditions for the disbursement of grants. These are;

- $30 \%$ for tone of the school, discipline organization and moral instruction

- $20 \%$ for adequate and efficiency of teaching staff

- $40 \%$ for periodical examinations and general progress

- 10\% for buildings, equipment, sanitation

The 1916 code also made great achievement as it gave the power to inspect or obtain information from non-assisted schools that were increasingly growing in the South. It also stated age limit of pupils in infant and elementary schools system. It in addition, approved Religious instruction as an examinable subject.

Education in Nigeria was administered differently as two departments by the colonial government for one and half decades. it was only in July 1929 that the northern and southern education departments were merged by the then Director of Education - ERJ Hussey; It is not surprising according to Osokoya (2012) to observe therefore, that five decades after attaining political independence, the north and south Nigeria remained distinct socio-cultural, economic and political zones. Following the country's colonial experience and different regional orientation, administration of education has taken different forms in different parts of the country.

Education Ordinances, as noted by Ajayi and Oni, were promulgated one after the other adding and improving on the previous ones, but very significant was the period of regionalism in the 1950s through MacPherson's Constitution. The regions - East, North and West started legislation on educational matters for the control and effective administration of education in their respective regions. This, of course brought about impressive changes and development in the regions and consciousness of the imperative of being formally educated was heightened.

\section{Post-Independence Accounts on Educational Administration in Nigeria}

From the foregoing, the Nigerian education system that started with the missionaries as early school administrators was characterized with numerous shortcomings which the colonial government came to the rescue through series of Ordinances and Codes. Since after the Nigerian independence, particularly from the 70's, administration and control of education system became the responsibility of Federal, State and Local governments. The Governments in Nigeria have been playing very important administrative roles and exercising considerable control on the Nigerian education system.

This control was further demonstrated by Nigerian Government, starting with the EastCentral State which according to OkorosayeOrubite (2002) enacted in 1970, an edict taking over primary and secondary education from their original proprietors, i.e. the missionaries and the voluntary agencies. This can unequivocally be remarked as the beginning of government's exclusive control of education in Nigeria. Five years after, specifically in 1975, the Federal Military Government promulgated same take-over of school law (Military Decree), tagged "The Government Take-Over of School Validation Decree, 1975". This time, it was regional, but 
nation-wide. However, Okorosaye-Orubite (2002:19) also informs that from 1979, communities and non-governmental organisations have been granted the right and encouraged to establish and manage schools within the government guidelines.

The role of Government in educational administration as remarked by Ajayi and Oni (1992) is essentially that of formulation, dissemination, and inspection and supervision of broad plans and general policy guidelines; as well as the general conduct of education practices throughout the country. Most significant too, is the 1969 Curriculum Conference that evolved a direction for how and what Nigerian education should be. The end product of this conference was the birth of the National Policy on Education (NPE). NPE is an educational policy document of Nigeria first issued in 1977 and revised at various times in 1981, 1989, 1998 and currently the 2004 edition (Abdulrahman, 2012).

The NPE is the working document for both educational and school administration in Nigeria. This document spells out how different aspects of education can be carried out and implemented at all levels. In view of this, the Online Nigeria (2013) reports that Federal government coordinates education planning, policy and finance through the National Council on Education, which comprises all Commissioners and Minister of Education in the country and the Joint Consultative Committee of Education.

The aforementioned can be regarded as educational administration, where in this context, President, the Minister of the Federal Ministry of Education, the Permanent Secretary and other Federal Officials are the administrators of education in their respective capacities. The role of formulating and determining National policy on education to ensure uniform standards and quality control; coordination, advisory, inspection, planning, research, evaluation etc characterized the administration of education in the country. Generally, the government of Nigeria has bodies and agencies that assist her in the administration and management of education.

a) National Council on Education (NCE) and Joint Consultative Committee on Education (JCCE)
It will be a very big vacuum to examine educational administration in Nigeria without a mention of the duo of National Council on Education and Joint Consultative Committee on Education. NCE is a council of the Minister and the State Commissioners of Education, meeting on rotational basis across the States to deliberate on issues and trends in the practice of education at all primary to secondary levels of education, as well as teacher, technical education and so on. NCE's recommendations are always in line with the Nigeria's national objectives on education. On the other hand, JCCE is an independent body of professional educators acting in advisory capacity to both the Federal and State Ministries of Education, Universities, Institutes of Education, the West African Examination Council, and all other education agencies.

As noted in an online resource - the main functions JCCE are not limited to: influencing educational development in the country, offering professional officers a forum for exchange of ideas and information and reconciling professional views in order to evolve a harmonious national educational system.

The Federal Government of Nigeria is the supreme educational administration body with numerous parastatals and agencies that help in execution of governmental functions and educational tasks. These agencies are by law established to carry out different educational responsibilities on behalf of the Federal Government. In the same manner, the Federal Minister of Education plays a vital role in the maintenance of educational standards nation-wide by operating national organisations which are devoted to the development of specialised aspects of Education. Such organisations include the Federal Inspectorate Service and soon. Specifically, the discussion on this shall focus on:

\section{b) Nigeria Education Research and Development Council (NERDC)}

The Nigerian Educational Research and Development Council (NERDC): The Council was set up by Decree Number 31 of August 1972, as Nigerian Educational Research Council (NERC) and has the mandate which spans the encouragement, promotion and coordination of educational research programmes. They engage in identification of educational problems, establishment of the order of priority to be given to 
such problems, periodic compilation and publication of a list of completed research projects, and establishment and maintenance of research and development library to which new educational books and other related publications may be deposited.

In addition to the above, NERDC's mandates also covers sponsoring of national/international education conferences; maintaining relationships with corresponding educational research and development bodies locally and internationally; setting up pilot curriculum projects in educational institutions; organising teacher education programmes for new techniques and approaches to curriculum development; and produce syllabus and instructional materials for use in Nigerian schools. This agency had an amended decree of its establishment, formally promulgated in 1988. Decree No. 53 of December, 1988 proclaimed the merger of Nigeria Education Research Council (NERC); Comparative Education Study and Adaptation Centre (CESAC); the Nigerian Book Development Council (NBDC); and the Nigerian Language Centre (NLC). Nigerian Educational Research and Development Council's popular function is their active involvement in curricular review and renewal.

\section{c) National Universities Commission (NUC)}

Another important agency of government on the issue of University education in Nigeria is the National Universities Commission (NUC): This body was statutorily established by Decree No. 1 of January, 1974 to advise Government on all aspects of University education as well as coordinating, financing and the over-all development of University education in Nigeria. Importantly too, the NUC also ensures

- orderly development of university education,

- the maintenance of high standard and avoidance of unnecessary and wasteful duplication of academic programmes, faculties and facilities.

Ultimately, NUC is empowered to advise the Federal Government through the Minister of Education on the creation of new universities and other degree awarding institutions. Also, NUC's responsibilities further include:

- distribution of government grant in accordance with a set formula
- collection, analysis and furnishing the Government, information relating to university development and education in Nigeria, and

- acting as the agency for channelling all external aid to Nigerian universities.

d) Other tertiary education regulatory bodies include:

i. National Business and Technical Education Board (NABTEB): NABTEB formerly known as National Board for Technical Education (NABTE) and was established by Act No. 9 of 1977 to regulate industrial, commercial, professional interests, including polytechnics, colleges of technology, vocational training and technical teacher institutions.

ii. National Commission for Colleges of Education (NCCE):

NCCE was established by enabling Decree No. 3 of 13th January, 1989. This body performs the functions of regulating teacher education falling outside the universities and polytechnics. Also performs other functions relating to matters on teacher education, including finance, review of personnel conditions of service etc.

\section{Agencies on Administration of Public Examinations}

e) West African Examinations Council (WAEC)

So long a time, West African Examinations Council (WAEC) dominated the Nigeria's examination scene as the only Federal Government instrument for the conduct and regulation of certain examinations in the country. WAEC conducts

i. the West African School Certificate examination

ii. the General Certificate of Education examination mainly at the ordinary level and sparingly at the advanced levels,

iii. the Royal Society of Arts Examination,

iv. the City and Guilds,

v. the National Common Entrance Examination , though defunct now, because of UBE.

The review of WAEC syllabus is almost frequently carried out in order to meet the needs of the country. Today, WAEC has developed syllabuses in such areas as elementary surveying, applied electricity, auto-mechanics, basic 
electronics, wood work, metal-work, business methods, statistics, principles of accounts, shorthand, typewriting and commerce.

b) National Examination Council (NECO): First and indigenous examination body - the National Examination Council (NECO) was born in January 1998, following the reports and recommendations of series of Federal Government Commissions and panels. Among these Commissions and panels were the Sogbetun Commission (1977), the Augulu Panel (1982), the Osiyale Committee 1993, the Etsu Nupe Panel. NECO as an Examination Council in the country according to Online Nigeria (2013) came to relieve WAEC of some of its obvious burdens. NECO has its headquarters in Minna, Niger State.

\section{The Joint Admission and Matriculation Board (JAMB)}

The Joint Admission and Matriculation Board, established by a decree in 1977, is one of the Boards in the Nigerian Educational System. It is responsible to the Federal Ministry of Education. A registrar is appointed for JAMB to take charge of affairs of the Board. The Board, when established was first responsible according to the decree establishing it, for the general control of the conduct of University Matriculation Examination (UME) for admission into all Universities in Nigeria for approved undergraduate courses leading the award of first degrees - Bachelor's degree. Today, JAMB has a much more responsibility beyond University's entrance examination. JAMB has the mandate of the Federal Government of Nigeria to organise entrance examinations for admission into Polytechnics and Colleges of Education, leading to the award of Ordinary/Higher National Diploma (OND/HND) and National Certificate of Education (NCE) respectively. This new mandate has brought about a change in nomenclature of JAMB examination from University Matriculation Examination (UME) to Unified Tertiary Matriculation Examination (UTME). This Board is full of innovative ideas that are not limited to express release of results. At present, the JAMB Board is assiduously working to ensure that its examination is fully automated and electronic.

\section{d) The National Teachers Institute (NTI)}

The NTI was established in 1974 by the Federal Military Government after due consultations between Nigeria educational advisers and
UNESCO experts. According to the Online Nigeria (2013), the intent of National Teachers Institute's establishment was to upgrade teachers and to improve the quality of Nigeria education in preparation for the Universal Primary Education scheme which was being conceived then.

NTI is in actual fact located in Kaduna, but operates a nationwide programme with study centres in all States of the federation, to work for improvement in Teachers education. Through this, non-graduate teachers are eventually upgraded to graduate status and provided with facilities to acquire post-graduate qualifications, that is the Post-Graduate Diploma in Education (PGDE).

So also, there are other establishments which are Government's instruments in Nigerian educational administration as provided by Abdulrahman and Ogbondah (2007), thus:

i. National Commission for Nomadic Education (NCNE), responsible for the education of Nomads, migrant farmers and fisher-folks.

ii. National French Language Village (NFLV) in Badagry, to co-ordinate and provide avenues for the process of attaining fluency and proficiency in French Language .

iii. National Arabic Language Village (NALV) in Ngala, to co-ordinate and provide avenues for the process of attaining fluency and proficiency in Arabic Language

iv. National Institute for Nigerian Languages (NINLAN)

v. Nigerian Mathematical Centre (NMC)

vi. Universal Basic Education Commission (UBEC)

vii. National Commission for Adult Education (NCAE)

viii. Mass Literacy and Non-Formal Education (NMEC)

ix. Education Trust Fund (ETF), focused on financial intervention in education sector

\section{Educational Administration at the State \& Local Government Levels}

In Nigeria as a federation, the States have replica of some educational administrative roles at the federal level which are shouldered by the Governor through the state Commissioner for Education, Permanent Secretary who is a career officer and serves as adviser to the Commissioner. Others in this category at the State level include the Directors in different areas of administration, 
not excluding personnel management, finance and supplies, planning, research and statistics, inspectorate, support services etc. Other State Education officials are at the State Ministry of Education or its Liaison's Offices. Statutorily, the State Ministry of Education is charged with the responsibilities that are not limited to appointment or recruitment of teaching and non-teaching staff of secondary schools and some post-secondary schools under the control of the State Ministry of Education. Also, promotion, discipline, training and re-training of staff as well as the general welfare of staff constitute major responsibilities of the State Ministry of Education.

For primary education, Local Governments take responsibilities and at the Secondary Level, the responsibilities are borne by State Governments. As far the tertiary education administration is concerned at present, both the federal and state governments are constitutionally permitted to establish higher institutions, finance and run tertiary education, since it is now contained in the Concurrent Legislative List. At the Local Government level, some of the roles played by the State Ministry are replicated too, particularly on the issues concerning education at the primary level, including teachers' welfare, recruitment, promotion, discipline and others which are the responsibilities of the Local Government Education Authority (LGEAs) or LEAs, as my be referred.

\section{Administration at the School Level}

As earlier maintained, administration at the school level is derived from the principles of educational administration which is extensive and broader than the school administration. Educational administration is more of formulation, dissemination, coordination, inspection and supervision of broad plans and general policy guidelines. So, Wikipedia (2012) renders educational administration as a discipline within the study of education that examines the administrative theory and practice of education in general and educational institutions and educators in particular. The field ideally distinguishes itself from administration and management through its adherence to guiding principles of educational philosophy. Therefore, school administration is at the micro level of administration, operational within the school setting.

Administration at the schools' level cannot be in a more elaborate manner in this paper, because of the simple fact that there are uncountable number of schools in Nigeria and practically unrealistic to capture or treat them individually and independently in terms of school administration documentations one by one, from inception till this present review. Therefore, the only task of this writer has been to review historically how we have come to this level we are about administration of education and school administration in Nigeria. And, since this book is a collection of issues on school administration, to be addressed by different scholars in the field of education, this writer restricted himself to historical evolution and development of school administration in Nigeria. However, a briefs about the workings of school administration and its perceived problems are given consideration as additional hints to wrap up the paper.

\section{School Administration - How It Works (Characteristics)}

As earlier portrayed, whatever that constitutes school administration (micro) must have its source from educational administration. It is therefore good to clarify that whatever the administrative roles or tasks of the leadership of the school system, particularly the principal in the case of secondary school must be coming from the ministry or its inspectorate unit who hand down to the school administrators the government's policy directives and guidelines for internal running of the school.

A template of School Act (2006), Sections 20, 60, 61, 113 - St. Thomas Aquinas R.C.S.R.D. portrays school administration with a clear cut instrumentality or workings of school administration which flows-in from the instrumentality of educational administration (government's guidelines) with which the school administrators apply and implement in the schools. Thus, the Superintendent, its replica in Nigeria: (permanent secretary/director/education officer, usually from the ministry of education) shall assign a principal to each school.

The principal is responsible to the Superintendent (usually government ministry's official).

The principal according to the template and by a way of replication is responsible for:

- providing instructional leadership in the school;

- ensuring that the instruction provided by the teachers employed in the school is consistent with the courses of study and education 
programs prescribed, approved or authorized pursuant to this Act;

- evaluating or providing for the evaluations of programs offered in the school;

- ensuring that students in the school have the opportunity to meet the standards of education set by the Minister;

- directing the management of the school;

- maintaining order and discipline in the school and on the school grounds and during activities sponsored or approved by the Board;

- promoting cooperation between the school and the community that it serves;

- supervising the evaluation and advancement of students;

- evaluating the teachers and other staff employed in the school;

- subject to any applicable collective agreement and the principal's contract of employment, carry out those duties that are assigned to the principal by the Superintendent (ministry or its official) in accordance with the regulations and the requirements of the School Council/Board and Superintendent;

- achieving the mission and educational goals established for the Division;

- providing assistance in the selection, deployment, development, reprimanding and making recommendations regarding tenure and termination;

- planning and controlling expenditures related to local school based budget; and

- other duties as assigned by the Superintendent.

The vice-principal is responsible to the principal, therefore the principal is responsible to develop a job description which outlines the specific duties of the vice-principal. In the absence of the principal, one vice-principal will be designated by the Principal or directly by the Superintendent to be responsible for the operations of the school. Other administrative roles or tasks are carried out by different school officers as assigned to them by the principal. These include Head of Departments, Form Masters, Subject Teachers, Hall Warden, Bursar/Account Officer, House Masters, even the School Prefects etc. In Nigeria, punishment of erring school pupil/student rests within the jurisdiction of the school head/principal only. This is not known to many people involved, including teachers; that no one has the right to flog a pupil other than the principal. However, this can be carried out by the teacher or any other school personnel, only if such power is delegated by the school head/principal.

\section{Problems in School Administration}

School administrators are responsible for developing and preserving the educational experience of teachers and students. Their duties range from selecting appropriate curriculum models to managing school finances to collaborating with community partners. However, looking at school administration in its assessment Sheahan (2013) asserts that "not all school administrations are effective at what they do. Problems may arise that can lead to a breakdown in the education system and diminish the learning experience of students". In this case, some of the problems of school administration as variously are given below:

a) Poor Leadership: Poor leadership can be the downfall of school administration. Strong leaders possess the ability to formulate progressive and realistic objectives, devise organizational strategies, maintain regular communication with others and work collaboratively with staff in a positive and encouraging way. Many times, those who are elected into school administrative positions are faculty who have demonstrated outstanding work over the course of many committed years to the school. However, they may not have leadership experience behind them or understand the fundamental elements involved in academic leadership and the politics that come with it. Consequently, poor leadership can disrupt the school environment and make it difficult for teachers and students to get what they need out of the academic experience.

b) Lack of Administrative Involvement: When school administrators are not involved at the classroom level, they are unable to fully understand how their teachers' classrooms are managed. This works as a disadvantage because it creates 
a breakdown between the administrative and academic sides of a school. Administrative involvement with teachers and classrooms can help school leaders understand what types of improvements must be made, and the information they learn can be valuable in shaping teachers' classroom budgets. Administrative involvement also shows teachers that the leaders of the school have an interest and appreciation for the work that is being done by faculty and students.

c) Weak Community Relations: School administration leaders must work with community members to create strong partnerships that will be mutually beneficial. When administrators fail to establish ties in the community, they miss out on working with others who could potentially help the school with fundraising activities or charitable donations for school improvement efforts. Administrators may see the results of weak community relations in the thinning of their school year budgets.

d) Favouritism: School administrators must be neutral, unbiased and not show favouritism toward particular teachers, faculty, students, parents or community partners. While some politicizing may be inescapable, problems can arise when academic leaders do not exert fair and impartial relations. Teachers may become less committed to the school if they feel like they are being treated less fairly than other teachers, or parents -- with similar feelings regarding their children -- may react by switching their children into other schools.

e) Ethics: Ethics pertain to social concepts of what is right and what is wrong. Every school has an ethical code by which staff must adhere. If school administrators break the ethical code, they risk bringing hardship to the school as well as their own careers. Ethical issues can include facing conflicts of interest, conducting inappropriate relations with other individuals or laundering money from the school budget.

\section{Conclusion}

A clarification is made, portraying how we have come to where we are about school administration in Nigeria. School administration as maintained earlier started by the Christian missionaries who thronged Nigeria for evangelism, but seeing how effective evangelism would go by adding educational provision led to school establishment. The establishment of schools by the missionaries required administering and managing those schools to complement their evangelism. Though, competition and rivalry among the missions in winning souls (converts) brought about the inadequacies that characterised the missionaryprovided education to Nigerians. These inadequacies that characterised missionary education generated criticisms which compelled the Colonial Government who themselves had no original intention to assume responsibilities for education; to change their lackadaisical attitudes towards education of their colonial subjects by becoming responsive.

Eventually, the colonial government, through her series of Educational Ordinances and Codes and the initial grant-in-aid marked the beginning of what can be regarded as educational administration in Nigeria. The Government's administration of education continued, even in the post-colonial Nigeria; resulting in the birth of several agencies of Government and parastatals, such as WAEC, NECO, JAMB, NUC, NERDC, NMC, NINLAN, NABTEB, NCCE, NCNE, NMEC and many others. National Policy on Education was evolved for the country, from which all other activities involved in school administration are sourced and implemented at different levels of education.

Finally, the historical pictures of where we started, where we are and where we are going; provide us with the opportunity to assess, appraise, evaluate and re-evaluate what we have done, what we are doing, what we are yet to do and how we can improve or make amend. So, looking at theme like that of this book from a historical perspective is not at all out of place, as anyone who forgets his history is deemed to commit errors of the past, and repeating the errors 
of the past means a failure to make experience the best teacher to learn from.

\section{Recommendations}

The problems are surmountable if government can be proactive in the policy formulation, which is implementation, not just formulation. Attitudinal change will also go a long way to streamline the system and desired goals achieved. School leadership uprightness compels other personnel to be serious. If school leaders are not corrupt, the subordinate will never be close to corruption. If right pegs are put in the right holes, then there will be no grievances or demoralised disposition. If rules and regulations are obey by all stakeholders, from government officials, parents and their children (students), school head, teachers and other personnel; then the administration of school shall run without blemish.

\section{References}

[1] Abdulrahman, Y. M. (2014). Nigerian educational history and policy: The beginning of the past and past of the future. Port Harcourt: M \& J Grand Orbit Communications Ltd.

[2] Abdulrahman,Y. M. \& Ogbondah L. (2007). Policies Puncturing and Nurturing in Nigerian Educational Reforms and Implementation: African Journal for Contemporary Issues in Education (CONTEMPOR). CODAT Publication, University of Cape-Coast, Ghana. Vol. 1 (1\&2).

[3] Ajayi, T. And Oni, J. (1992). A functional approach to school organisation and management. Ijebu-Ode: Triumph Book Publishers.

[4] Boyd, W. and King, E. (1981). The History of Western Education. Akure: Fagbamigbe Publishers. Eleventh Edition

[5] Fafunwa, A. B. (1974). History of Education in Nigeria. London: George Allen \& Unwin Ltd.

[6] Foster, P. (1980). Regional disparities in educational development. In G. Carron and T. N. Chua. Regional disparities in ducational development: diagnosis and policy for reduction. Paris: UNESCO.

[7] Glossary of Education (2012). School administration. $2006 \quad-\quad 2013$ Education.com, Inc. www.education.com
[8] Johnson, S. (2013). Types of school administration. eHow 1999-2013 Demand Media, Inc.

[9] Learn.org (2018). What is school administration?

https://learn.org/article_directory/Educatio nal_administration_FAQs.html

[10] Okorosaye-Orubite, A. K. (2002) Historical Foundations of Education. In J. M. Kosemani (Ed) Introduction to Education. Port Harcourt: Port Harcourt Press Ltd.

[11] Online Nigeria (2013). Educational administration and organisation. Community Portal of Nigeria. wwww.onlinenigeria.com/Educational-

Administration-and-Organisation

[12] Osokoya, I. O. (1995). History and policy of education in world perspective. Ibadan: AMD Publishers.

[13] Osokoya, I. O. (2012). Five Decades of free universal primary/basic ducation in Nigeria and the challenges of sustainability. A public lecture delivered at the $10^{\text {th }}$ Professor Kosemani Memorial Annual Lecture, University of PortHarcourt, Rivers State - Nigeria.

[14] Rand (2018). Educational administration. Rand Corporation - Objective analysis and Effective Solutions. https://www.rand.org

[15] School Act (2006). School administration. Administrative procedure manual, No. 38. St. Thomas Aquinas R.C.S.R.D. Sections $20,60,61,113$

[16] Sheahan, K. (2013). Problems in school administration. eHow 1999-2013. Demand Media, Inc.

[17] Taiwo, C. O. (1980). Nigerian education system: past, present and future. Lagos: Thomas Nelson (Nigeria) Ltd.

[18] Wikipedia (2012). Educational administration. Wikimedia Foundation, Inc. www.wikimediafoundation.org

[19] Wikipedia (2017). Educational administration. Wikimedia Foundation, Inc.

https://en.wikipedia.org/wiki/Category:Ed ucational_administration 